\title{
A SZERVEZETI KULTÚRA MÉRÉSI KULTÚRÁJA: KÉRDÖÍV-TIPOLÓGIA ÉS KULCSDIMENZIÓK
}

A tanulmány célja, hogy bemutassa a kérdőíves felmérések szerepét a szervezeti kultúra kutatásokban. A kitűzött cél elérése érdekében a szerző: 1) elhelyezi a kérdő́ives kultúrakutatásokat a szervezeti kultúra kutatási terében; 2) a szervezeti kultúra kérdő́iv-típusait definiálja az általuk vizsgált kultúraszint (magatartás, érték) és az elemzés fókuszában álló összefüggés (vagy annak hiánya) függvényében (kultúra teljesítmény, kulturális illeszkedés); 3) meghatározza a kulturális kulcsdimenziókat.

A szervezeti kultúra kutatói közösségét kezdetektől megosztja az a kérdés, hogy a kultúra vajon divat, a menedzseri érdekeknek az elméletbe való beszivárgása, vagy valós összefüggéseket rejtő terület. Már a fogalom felbukkanását (az 1970-es évek vége) markáns kettőség jellemezi. Egyszerre jelentek meg (Barley - Meyer Gash, 1988):

- menedzsereknek és gyakorlati szakembereknek szánt cikkek, amelyekben a szerzők a szervezeti értékek, normák, szimbólumok megismerését a szervezeti hatékonyság és kontroll növelése reményében szorgalmazzák (pl. Peters - Waterman, 1982),

- kutatói közösség számára írt cikkek, konferenciaelőadások, amelyek a kulturális antropológia hagyományaihoz visszanyúlva a szervezeti kutatások megújulási lehetőségét látják a szervezeti kultúrában (Pettigrew, 1979).

A szervezeti kultúra fogalmát megjelenése óta számos megközelítésben vizsgálták, és népszerűsége ellenére sem letisztult a fogalom-használat. A témakörben elvégzendő újabb kutatások ily módon nem egyértelmű elméleti alapokra épülhetnek (Bokor, 2000; Parker, 2000). Ez szükségessé teszi, hogy a kutatók tegyék explicitté az elméleti gyökereket és az abból fakadó követelményeket, valamint a használható módszert. Ebben segítenek az egyes kutatási irányzatokat, iskolákat különböző dimenziók mentén kategorizáló összefoglaló cikkek (Smirchich, 1983; Allaire - Firsirotu, 1984; Meyerson -Martin, 1987; Bokor, 2000; Heidrich, 2000; Parker, 2000; Martin - Frost - O'Neill, 2004; Jávor - Rozgonyi, 2005). Tanulmányomban a szervezeti kultúra kérdőívek kultúrakutatásokban betöltött szerepének meghatározásához a Martin - Frost - O’Neill (2004) által definiált átfogó kutatási keretet tekintem kiindulópontnak: összefoglaló modelljükben elhelyezem a kérdőíves kutatásokat, az egyes dimenziók mentén felmerülő kérdésekre, dilemmákra adott jellegzetes válaszaik alapján. Ezt követően a kérdőívtipológiát, valamint a kulturális kulcsdimenziókat definiálva rendszerezem kutatási klaszteremet.

\section{A szervezeti kultúra vizsgálódási kerete}

A szervezeti kultúra kutatások Martin - Frost O’Neill (2004) által felvázolt háromdimenziós terének tengelyeit a kutatók szervezetelméleti, ismeretelméleti és módszertani választásai határozzák meg. A főtengelyt a Meyerson - Martin (1987) által meghatározott integrációs, differenciációs és fragmentációs kultúra megközelítések definiálják, amelyek aszerint különböztetik meg az egyes kutatásokat, hogy mennyire tekintik egységesnek a szervezet kultúráját. Az integrációs megközelítés egyértelműséget, szervezeti szintű konszenzust, a különböző kultúra szintek, kulturális manifesztációk között konzisztenciát feltételez. A szervezeti kultúra ebben az értelmezésben az azonosulás, a kiszámítható és előrejelezhető cselekvés garanciája. A differenciációs megközelítés a konszenzust az egyes szubkultúrák szintjén értelmezi, elfogadva az egyes szubkultúrák között feszülő ellentéteket, értelmezési és hatalmi különbségeket. A fragmentációs megközelítés a többértelműség (ambiguity) és változás (flux) fogalmakat állítja a középpontba, elvetve a konszenzus gondolatát mind szervezeti, mind csoport szintjén (1. ábra). 
A szervezeti kultúra elemzési kerete

(Martin - Frost -O'Neill, 2004)

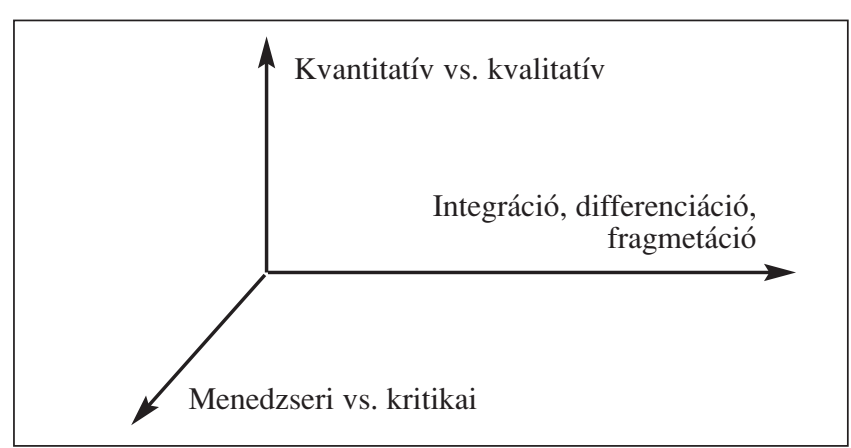

A szervezeti kultúra kutatások felosztása további két tengely mentén árnyalható. Az elsőnek megfelelően beszélhetünk menedzseri („értékmérnök”) és kritikai ${ }^{1}$ megközelítésekről, annak függvényében, hogy a kutatók mely szervezeti szereplők érdekeit részesítik előnyben, míg a második mentén a kvantitatív vs. kvalitatív módszertani vita azonosítható.

A szervezeti kultúra kutatások fentiekben definiált háromdimenziós terében jellegzetes klaszterek figyelhetőek meg, a kutatók egyes tengelyek mentén való választásai függvényében (Martin, 2002).

A kvantitatív kutatások az integrációs megközelítésnek megfelelően jellegzetesen azon dimenziókra fókuszálnak, melyek szervezeti szinten jellemzőek. Faktoranalízis segítségével kizárják azon vonatkozásokat melyek nem generálnak szervezeti szinten konszenzust. A kvantitatív kutatások gyakran menedzseri vagy szakértői mintákon alapulnak, menedzseri érdekeket részesítve előnyben. Ezen kutatások a szervezeti kultúrára, mint lehetséges magyarázó változóra tekintenek, és ok-okozati összefüggéseket keresnek a kultúra és különböző eredményváltozók között. A fentieket mérlegelve számos kutató választja a kérdőíves felmérést. A legtöbb kultúra kérdőív előre megfogalmazott szervezeti értékekkel, vagy normákkal való egyetértésre kérdez rá, és ezek feltárásán keresztül igyekeznek megragadni a szervezeti kultúrát (Hofstede et al., 1990; House et al., 2004a stb.). A kérdőívek kultúra feltárására való alkalmasságát támogatja Hofstede et al., (1990) megállapítása is, mely szerint a kultúra szervezeti megragadására szervezeti szinten a gyakorlatok (leíró megközelítés), míg társadalmi szinten az értékek (normatív megközelítés) ad megbízhatóbb képet. A kultúra kérdőívek további előnye, hogy megismételhetőek, lehetővé teszik a szervezetek közötti összehasonlítást, hasznos keretet nyújtanak a szükséges változtatások feltárásához, valamint különböző statisztikai módszerekkel elemezhetőek, összevethetőek más kutatási eredményekkel (Xenikou - Furnham, 1996). Ugyanakkor a kérdőívek nem teszik lehetővé a mélyebb, helyi megértések feltárását, beszűkítve az eredmények magyarázatának lehetőségeit is.

A kvalitatív kutatások általában a kulturális manifesztációk széles palettáján vizsgálódnak, a mély megértést és nem az általánosíthatóságot tűzve ki célul. A mintavétel a szervezetek különböző hierarchia szintjeit érinti, a szervezeti szereplők érdekei között levő különbségeket, ellentmondásokat és feszültségeket is a felszínre hozzák. A legtöbb kvalitatív kutatás a differenciációs vagy fragmentációs megközelítést részesíti előnyben (kivételek léteznek, Barley (1983) és Martin et al., (1983) kutatásai, melyek az integrációs hagyományok jegyében születtek).

A fentiek alapján elmondható, hogy két nagyobb csoport körvonalazódik a szervezeti kultúra kutatási terében (kivételek persze léteznek): 1) integrációs, kvantitatív, menedzseri érdekeket érvényesítő kutatások; 2) kvalitatív, nem-menedzseri, differenciációs vagy fragmentációs szempontokat tükröző kutatások (Martin, 2002).

A kérdőíves kultúrakutatások a fentiekben definiált kutatási térben - figyelembe véve a kutatók alapfeltevéseit, valamint módszertani választását - az első klaszterhez tartoznak. További pontosítások szükségesek azonban a szervezeti kultúra fogalmának meghatározására.

\section{A szervezeti kultúra integrációs, menedzseri és kérdőíves kutatásai}

Az elemzési keret egyértelmű meghatározásának érdekében a fentiekben definiált klaszterhez tartozó kutatások körét tovább pontosítom annak alapján, hogy a kutatók hogyan operacionalizálják a kultúra fogalmát, mely tartalmi elemeket veszik figyelembe annak meghatározásakor. A kulturális elemzésnek ilyen irányú leszűkítését a vizsgált megközelítés teszi lehetővé, mert konzisztenciát feltételez az egyes kultúraszintek között.

A szervezeti kultúrát a vizsgált klaszterbe sorolt kutatások objektív entitásként, behaviorista és/vagy kognitív jellemzők készleteként értelmezik (Brown, 1995). A csoporton belül megkülönböztethetünk továbbá specialista, valamint generalista kutatásokat (Bokor, 2000; Martin, 2002): előbbiek egy vagy két kulturális megnyilvánulási formát állítanak a középpontba (pl. magatartási normák, értékek), míg utóbbiak a kultúra fogalmát számos tartalmi elemén keresztül ragadják meg. Ez utóbbira példaként említhető Bakacsi (1996) meghatározása, mely szerint a „,szervezeti kultúra nem más, mint a szervezet tagjai által elfogadott, közösen értelmezett előfeltevések, értékek, meggyőződések, hiedelmek rendszere" (Bakacsi, 1996: 226. o.). 
Az egyik legmeghatározóbb definíció az integrációs megközelítés specialista vonulatában Schein (2004) nevéhez füződik, aki szerint a szervezeti kultúra „alapvető feltevések rendszere, amelyeket egy adott csoport talál ki, fedez fel vagy fejleszt ki a külső adaptáció és a belső integráció problémáinak megoldása során. Azokat az alapvető feltevéseket, amelyek elég jól működnek ahhoz, hogy érvényesnek fogadják el okket, a szervezetbe újonnan belépő tagoknak el kell sajátítaniuk, mint a szóban forgó problémák megoldásának egyedül helyes észlelési, gondolkodási és érzelmi mintázatát" (Schein, 2004: 17. o.). Ez a megközelítés tehát a kultúrát egy kollektív tapasztalati tanulási folyamat eredményének tekinti. A scheini jéghegy modell szerint az alapvető feltevések jelentik a szervezeti kultúra legmélyebb szintjét, amelyek azért tekinthetőek meghatározó fontosságúaknak, mert nem tudatosak, ennélfogva megkérdőjelezhetetlenek, maguktól értetődőek. A kultúra következő szintjét már a tudatos szinten létező értékek alkotják. Ennek a szintnek Schein kritikus szerepet tulajdonít, mert ez alapján a szervezeti tagok viselkedése előre jelezheto, valamint a frissen belépők is ezeket sajátítják el a szervezeti szocializáció során. A scheini kultúra jéghegy látható, legfelső szintjét a tárgyiasult jelenségek (pl. szakzsargon, rítusok, történetek, ceremóniák, épületek stb.), szimbólumok és magatartási formák képezik, melyek könynyen megragadhatóak, de nehezen értelmezhetőek, mert jelentésüket a mélyebb kultúrarétegek befolyásolják. A tárgyiasult jelenségek, szimbólumok és alapvető feltevések vizsgálata általában a kvalitatív kultúrakutatások tárgyát képezi, ily módon tanulmányom keretei között nem foglalkozom vele.

A specialista kutatások jelentős részét azon vizsgálódások képezik, melyek a kultúrát, mint értékrendszert és/vagy magatartási jellemzők tárházát definiálják. Ezen elméletek szerint az értékek és magatartási normák főbb dimenziókba tömöríthetőek, amelyek révén az egyes szervezeti kultúrák leírhatóak, valamint összehasonlíthatóak.

Összefoglalóan: vizsgálódásom fókuszában az integrációs, menedzserialista, kérdőíves felmérést alkalmazó, az értékekre és magatartási normákra fókuszáló specialista kultúrakutatások állnak. O'Reilly és Chatman (1991) kultúra meghatározását fogadom el munkadefinícióként, amely szerint a szervezeti kultúra ${ }^{2}$ „közös értékek és normák rendszere, melyek befolyásolják a szervezeti tagok viselkedését”, ahol az „értékek absztrakt eszmények, a normák konkrét elvek, szabályok, amelyek követését a csoport minden tagjától elvárják" (Giddens, 1995).

A fentiekben elhelyeztem a vizsgált kutatásokat (érték- és normaalapú, integrációs, kérdőíves felmérések) a szervezetikultúra-kutatások háromdimenziós te- rében. A következőkben a vizsgált klaszter kutatásait egységes keretbe rendezem 1) a szervezeti kultúra kérdőív típusai, valamint 2) kulturális kulcsdimenziók meghatározása révén.

\section{A szervezeti kultúra kérdő́v-típusai}

A szervezeti kultúra kérdőíveinek áttekintésével és rendszerezésével célom, hogy átfogó képet nyújtsak a rendelkezésünkre álló eszközökről, megkönnyítve a kutatási céloknak legmegfelelőbb eszköz kiválasztását.

A szervezeti kultúra fentiekben definiált klaszterének az első rendszerező elvét a kutatások célja jelenti, melynek függvényében két fő csoportot különböztetek meg (Ashkanasy - Broadfoot - Falkus, 2000 alapján):

- Kategorizáló felmérések: a szervezeteket különböző kultúratípusokba sorolják. Az egyes szervezeti kultúra típusok tartalmazzák a jellemző viselkedési mintázatok, értékek leírását, lehetővé téve az összehasonlításukat, a kívánatosnak tartott változtatási irányok kijelölését. Következésképpen a kategorizáló felmérések besorolják a szervezetet az előre meghatározott, és egymást kölcsönösen kizáró kultúratípusok valamelyikébe. A kategorizáló megközelítés korlátja, hogy véges számú, előzetesen definiált típusba sorolja be az egyes szervezeti kultúrákat, megoldatlanul hagyva egyrészt azon szervezetek esetét, amelyek bizonyos jellemzők mentén egy kategóriába sorolhatóak, míg más jellemzők mentén egy másik típus tagjai lennének, másrészt a vegyes szervezeti kultúrák esetét, amikor különböző szinteken, vagy szervezeti csoportok szintjén eltérő kultúratípusok a jellemzőek.

- Leíró felmérések: a szervezeti kultúrák jellemzését tűzik ki célként, meghatározott számú, előzetesen definiált, kulturális dimenzió mentén. Annak függvényében, hogy a kultúrát milyen szervezeti változó magyarázó tényezőjeként használják, megkülönböztetek összehasonlitó felmérést, amelyik (első lépésben) nem keres szervezeti eredményváltozókkal kapcsolatos összefüggéseket, teljesítményalapú felmérést, mely azon kulturális dimenziókat méri, melyek a kutatók szerint a szervezeti teljesítmény növeléséhez vezetnek, valamint illeszkedési felméréseket, melyek az egyén és szervezet közötti megfelelést vizsgálják. A leíró megközelítés feltételezi, hogy a szervezeti kultúra értelmezhető, véges számú kulturális dimenzió mentén.

A kategorizáló kutatásokról tehát összességében elmondható, hogy a szervezet egészére koncentrálnak és bizonyos szervezeti kultúra típusok leírását valósítják meg a kérdőívek segítségével. A kérdőív egyes elemei az adott szervezeti típusokra vonatkozó olyan állítások, amelyeket a kutatók által fontosnak ítélt szer- 
vezeti jellemzőkről (pl. vezető szerepe, döntéshozatal módja, irányítás stb.) fogalmaznak meg. A leíró kutatások kulturális dimenziókat definiálnak, amelyek alapján jellemzik a vizsgált szervezeteket. A két kérdőívtípus közötti különbség megértését segítheti a következő metafora is. A kategorizáló kérdőívet kedvelő kutató olyan, mint az a vendég, aki előre elkészített virágcsokrot vesz a meghívónak, míg a leíró kérdőíveket preferáló kutató szálanként válogatja össze a virágkompozíció részeit, eltérő szín és illathatást érve el, ami azonban behatárolt a rendelkezésére álló virágfajták által.

Elemzési keretem második rendszerező elveként a Schein (2004) által meghatározott kultúraszinteket fogadom el és annak függvényében különböztetem meg a kérdőíves felméréseket, hogy az értékek (közbülső szint) vagy a magatartások (felszín) szintjén vizsgálódnak.

Az 1. táblázatban a fentiekben meghatározott rendszerező elvek mentén (kutatási cél, vizsgált kultúraszint) összefoglalom a legismertebb kérdőíves felméréseket.

\section{A magatartás szintjén vizsgálódó felmérések}

A scheini (2004) jéghegy látható szintjén vizsgálódó felmérések közül a Kilmann és Saxton (1983) által jegyzett CGS (Culture Gap Survey), valamint a Cooke és Lafferty (1986) szerzőpáros által fejlesztett OCI (Organizational Culture Inventory) kérdőívek váltak széles körben ismertté. Ashkanasy - Broadfoot - Falkus (2000), valamint Delobbe - Haccoun - Vanderberghe (2002), kérdőíveiket a korábbi években született kérdőívek dimenzióinak tartalomelemzése alapján alakítot-

\section{1. táblázat}

A szervezeti kultúra kérdőíveinek összefoglaló táblázata

(Ashkanasy - Broadfoot - Falkus (2000) alapján, kiegészítve)

\begin{tabular}{|l|c|c|c|c|}
\hline Szerző & $\begin{array}{c}\text { Megje- } \\
\text { lenés éve }\end{array}$ & $\begin{array}{c}\text { Kultúra } \\
\text { szintjei }\end{array}$ & $\begin{array}{c}\text { Kutatás } \\
\text { célja }\end{array}$ & $\begin{array}{c}\text { Kulturális } \\
\text { dimenziók } \\
\text { száma }\end{array}$ \\
\hline Allen és Dyer (NDI) & 1980 & magatartás & teljesítmény & 7 \\
\hline Kilmann és Saxton (CGS) & 1983 & magatartás & teljesítmény & 4 \\
\hline Sashkin és Fulmer (OBQ) & 1985 & értékek & teljesítmény & 10 \\
\hline Cooke és Lafferty (OCI) & 1986 & magatartás & illeszkedés & 12 \\
\hline Handy & 1986 & értékek & kategorizáló & 9 \\
\hline Quinn (OCAI) & 1988 & értékek & kategorizáló & 6 \\
\hline Hofstede & 1990 & $\begin{array}{c}\text { magatartás, } \\
\text { értékek }\end{array}$ & összehasonlító & 6 \\
\hline O’Reilly és ts. (OCP) & 1991 & értékek & illeszkedés & 5 \\
\hline Ashkanasy és ts. (OCP) & 2000 & magatartás & összehasonlító & 10 \\
\hline Delobbe és ts. (ECO) & 2002 & magatartás & összehasonlító & 5 \\
\hline Robert és Wasti & 2002 & értékek & illeszkedés & 2 \\
\hline GLOBE & 2004 & magatartás, & összehasonlító & 9 \\
\hline Patterson és ts. (OCM) & 2005 & értékek & összehasonlító & 17 \\
\hline
\end{tabular}

ták ki, azzal a céllal, hogy az új dimenziók segítségével átfogó és teljes képet nyújthassanak a vizsgálandó szervezetek kultúrájáról. A kutatók mindkét esetben empirikusan tesztelték a létrehozott eszköz érvényességét és megbízhatóságát.

Az OCP (Organizational Culture Profile) tíz dimenzióját részletesen is kifejtem, mert a későbbiekben, a kulcsdimenziók definiálásakor, hivatkozom rájuk (Ashkanasy - Broadfoot - Falkus, 2000):

Leadership: Vezetők, mint szerepmodellek, valamint a kultúra kialakításában, fenntartásában betöltött szerepük.

Struktúra: Hogyan határozza meg a struktúra a szervezeti tagok viselkedését; a szabályok, előírások hatása a szervezeti tagok viselkedésére, valamint a hatalom koncentrációja a szervezetben?

Innováció: A kockázatvállalás preferálása, az innovációra, kreativitásra való szervezeti nyitottság.

Teljesitmény: A munkahelyi teljesítmény hangsúlya a szervezetben, a teljesítmény szervezeti elismerése.

Tervezés: A szervezeti célok megfogalmazása, azok elérését támogató tervek készítése, valamint az elérésükre tett erőfeszítések hangsúlya.

Kommunikáció: Az információk szabad áramlásának lehetősége a különböző szervezeti szintek között, a kommunikáció iránya, a pletyka szerepe a kommunikációban.

Környezet: Az ügyfelek befolyása a szervezetre, valamint a szervezet hatása az ügyfeleire, a hasonló szervezetekre.

Humánus munkahely: Az egyén tisztelete és megbecsülése; emberközpontúság.

Egyén fejlesztése: Fejlesztési lehetőségek biztosítása az egyén számára, valamint ennek a jutalmazása szervezeti karrierlehetőségekkel.

Szocializáció: A szocializáció formalizáltsága, hatékonysága, valamint eredményessége (mennyire értik meg a szervezetet a frissen belépők).

Az ECO (Echelles de Culture Organisationnelle) magatartási szinten vizsgálódik a szervezetek közötti különbségekre (összehasonlításokra), valamint az akkulturációs folyamatokra fókuszálva. Az ECO-t is a releváns szervezeti kultúra kérdőívek áttekintése és tartalomelemzése révén alakították $\mathrm{ki}$, de az OCP kialakítási folyamatától egy fontos vonatkozásban különbözik. Az OCP esetében a kérdőív elemeit (item) és a dimenziókat is előzetesen, a szakirodalmi áttekintés alapján definiálták, míg az ECO esetében csupán a kérdőív elemeit határozták meg a szakirodalom alapján, a dimenziókat 
az empirikus kutatás adatain végzett faktoranalízis során állapították meg. Az ECO dimenziói a következők: Elismerés-támogatás, Elkötelezettség-szolidaritás, Innováció, Kontroll, Folyamatos tanulás.

\section{Értékek szintjén vizsgálódó felmérések}

\section{Kategorizáló kérdőivek}

A legelső kategorizáló kérdőív Harrison (1975) nevéhez kötődik (idézi: Ashkanasy - Broadfoot - Falkus, 2000), amely Handy által finomított változatában vált népszerű szervezeti kultúrát diagnosztizáló eszközzé. Handy szerint a szervezeti kultúra olyan karakterisztikája a szervezetnek, amely egyetlen alapvető értékként határozza meg a müködését. A Handy-féle kérdőív a szervezeti múködésre és tervezésre vonatkozó mondatkezdeteket tartalmaz, és minden egyes mondatkezdetet négy lehetséges folytatás (azaz négy különböző - a szervezeti viselkedésmintákkal, értékekkel kapcsolatos - állítás-értékelés) követ, melyek a kezdethez illesztve egy-egy teljes mondatot adnak. A folytatásként következő mondatrészleteket rangsorolni kell, majd a kérdőív végén az összesítést követően körvonalazódik a szervezet domináns kultúrája. A kérdőívnek van egy Jelenleg Létező Kultúra - és egy Kívánatosnak Tartott Kultúra része, lehetőséget teremtve az elvárt változtatási irányok kijelölésére.

A négy szervezeti típus a vezető szerepében, a szervezet környezetéhez való viszonyában, az irányítás, valamint a döntéshozatal módjában térnek el egymástól. Az egyes szervezet/kultúra típusok, valamint azok vezetőinek illusztrálására metaforákat használt: „pókhálő”, melynek védnöke Zeusz; „,görög templom”, melynek patrónusa Apolló; „mátrix”, melynek Handy nem választott isteni patrónust, ,, halmaz” vagy „galaxis”, amelynek patrónusa a görög istenek közül Dionüszosz

A másik, széles körben ismert, kategorizáló kérdőív Quinn nevéhez kötődik, aki hatékonyan működő szervezetek jellemzőit csoportosítva azonosította „Versengő Értékek" modelljének tengelyeit (Quinn - Rohrbaugh, 1983). Az így létrejött térnegyedek határozzák meg a modellkultúra típusait ${ }^{4}$. A négy kultúratípus alapján kidolgozták szervezetikultúra-kérdőívüket (Cameron - Quinn, 1999), az OCAI-t (Organizational Culture Assessment Instrument), mely hat dimenzió mentén vizsgálódik: fốbb szervezeti jellemzők, leadership, vezetési stílus, működési elvek, stratégiai irány, valamint szervezeti sikerkritériumok. Mindegyik szervezeti jellemzőre megfogalmaz négy, a különböző szervezeti kultúra típusnak megfelelő állítást, amelyeket a kitöltőnek súlyoznia kell (száz pontot elosztani a négy állítás között), annak függvényében, hogy mennyire jellemzőek a vizsgált szervezetre. A kérdőívnek van egy Kívá- natosnak Tartott Kultúra része is, mely lehetővé teszi az elvárt változásoknak a feltérképezését is.

A kategorizáló kutatások korlátjai kettősek: 1) az egyes típusok összehasonlíthatósága kérdéses, mert eltéró elméleti modelleket használnak; 2) az azonosítási folyamat is problematikus, mert a szervezetek a domináns kultúrájuk mellett más típusok jegyeit is felsorakoztatják (ez utóbbi jelenti a kutatásban résztvevők által megfogalmazott leggyakoribb kritikát is).

A korlátok felismerése ellenére el kell ismerni a kategorizáló kutatások népszerűségét, amelynek egyik lehetséges magyarázata, hogy képes a szervezeti tagok számára átfogó képet nyújtani a szervezetükről, az alkalmazott vezetési stílusról, valamint a kívánatosnak tartott változtatási irányról.

\section{Leíró kérdőívek}

\section{Összehasonlító kutatások}

A leíró, összehasonlító kutatások csoportjába tartoznak azon eszközök, melyek értékek (és magatartási mintázatok) mentén vizsgálódnak. Az eredmények interpretációját azonban nem más szervezeti mutatókkal való korrelációk jelentik, hanem sokkal inkább az a jellemző, hogy a szervezeti tagoknak visszacsatolva őket, közösen értelmezik az eredményeket, illetve szervezetek közötti hasonlóságokat keresve jellegzetes szervezeti kultúra klasztereket azonosítanak - Mármarosi (2002) GLOBE kérdőívvel, magyarországi szervezeti mintán végzett kutatása során négy szervezeti kultúra típust definiált.

Ezen csoportba tartoznak Hofstede et al., (1990) és House et al., (2004a) által végzett kutatások, melyek az összehasonlító kultúrakutatások hagyományaihoz híven, a szervezetet tekintették elemzési szintként, az összehasonlításra helyezték a hangsúlyt, valamint összefüggéseket kerestek a különböző elemzési szintek (társadalmi, iparági, szervezeti) között. A teljesítménnyel való összefüggések keresése nem lehet ezen kutatások célja, mert az előbbi kérdésre kapott válasz függvényében ez azt is jelenthetné, hogy az egyes társadalmi kultúrák hatékonyabbak más társadalmi kultúráknál.

Hofstede et al., (1990) húsz holland és dán szervezeti egységen (öt holland és öt dán szervezet 10-10 szervezeti egysége, eltérő iparágakból) végzett kutatásukban értékekre (ideális munkahely, általánosan kívánatosnak tartott értékek) és magatartásokra (pl. rítusok és hősök) vonatkozó állításokat fogalmaztak meg, melyeket egy öt fokozatú Likert skálán mértek. A kérdőív elemeit a vizsgált szervezeteknél végzett mélyinterjúk alapján definiálták, majd statisztikai módszerekkel validálták az így kialakított eszközt. Az egyes kultúra dimenziókat főkomponens elemzéssel határozták meg. Értékek szintjén három faktort definiáltak, 
melyek a teljes variancia 62\%-át magyarázták: 1) Biztonság; 2) Munka központúsága (a munka fontossága az egyén életében); 3) Hatalom. Az egyes értékdimenziók tartalmát vizsgálva megállapítható, hogy az első és harmadik dimenzió hasonlít a nemzeti szinten definiált Bizonytalanságkerülés, valamint Hatalmi távolság dimenziókhoz. A szervezeti gyakorlat (magatartások) szintjén hat faktort definiáltak, melyek értelmezését a visszajelző interjúkon szerzett információkkal gazdagították. 1) Folyamat vs. eredményorientáció; 2) Feladat vs. kapcsolatorientáció 3) Szervezeti vs. szakmai identifikáció; 4) Nyílt vs. zárt rendszer; 5) Erős vs. gyenge kontroll; (6) Szabály vs. gyakorlatorientáció. Kutatási eredményeik alapján a szervezeti kultúrák közötti különbségek a magatartás szintjén határozhatóak meg (értékek szintjén a nemzeti összehasonlításokban tapasztaltak nagyobb különbségeket). Következésképpen Hofstede et al., (1990) a szervezeti kultúrák leírására a magatartás szintjén definiált hat faktoros modelljüket javasolják .

A GLOBE (House et al., 2004a) egy többfázisú, nemzetközi kultúrakutatás, amely céljául tűzte ki a nemzeti-, szervezeti kultúrák és a leadership közötti összefüggések feltárását, valamint a kultúrák közötti összehasonlítást (nemzeti és szervezeti szinten egyaránt). A kutatás az első két fázison jutott túl (kérdőív fejlesztése és tesztelése, valamint a nemzetközi adatbázis összeállítása, elemzése), amely alapján bemutatom a GLOBE kultúradimenzióinak kialakítási folyamatát, valamint az egyes dimenziók tartalmát. A GLOBE kérdőívnek két változatát dolgozták ki: a szervezeti kultúra kérdőívet (Alfa kérdőív), valamint a társadalmi kultúra kérdőívet (Béta kérdőív). Az Alfa és Béta kultúra kérdőív tartalmazott egy leíró (észlelt) és egy normatív (kívánatos) részt, így mindkét elemzési szinten (társadalmi és szervezeti) magatartási és érték szintű mérés is történt. A GLOBE mintavételi stratégiájának alapkritériumai: 1), a válaszadók középvezetők; 2) minél több válaszadó egy adott szervezettől; 3) három rögzített iparágból (élelmiszeripar, telekommunikáció és pénzügyi szektor) legalább két szervezet; 4) adatok minden ország esetében legalább két iparágból; 5) minden nagy földrajzi régióból legalább három ország (House - Hanges, 2004).

A dimenziókat a priori alakították ki, három fő elméleti megközelítésre támaszkodva: 1) érték-hiedelem elmélet (feltételezi, hogy az értékek és hiedelmek befolyásolják az emberi viselkedést (Kluckhohn Strodtbeck, 1961; Hofstede, 1980); 2) implicit motivációs elmélet; 3) kontingenciaelmélet.

A GLOBE kultúradimenzióit és azok definícióit lásd e lapszám másik tanulmányában (Bakacsi, 2006).

Kiemelendő különbség a fentiekben leírt összehasonlító kultúrakutatások esetében, hogy Hofstede (2001) eltérő dimenziókkal, míg a GLOBE hasonló dimenziókkal mér eltérő kultúra szinteken (nemzeti és szervezeti).

Az összehasonlító kultúrakutatások objektív entitásként, szervezeti változóként kezelték a szervezeti kultúrát, és nem törekedtek a kultúra és szervezeti teljesítmény közötti kapcsolat feltárására. Ez közvetlen célként a teljesítményalapú felméréseknél jelent meg, illetve az illeszkedési felmérésekben - a munkavállalói elkötelezettség, mint közvetítő tényező közbeiktatásával - ugyancsak vizsgálták a kultúra teljesítményre gyakorolt hatását, (erre a következőkben bővebben is kitérek).

\section{Teljesítmény alapú felmérések}

A második kérdőívtípus fókuszában azon értékek állnak, amelyek révén a szervezetek sikeresek lesznek. Gordon és DiTomaso (1992) véleménye szerint a szervezet sikerességének kulcsa az az integrációs megközelítésnek megfelelő „erős” szervezeti kultúra, amelynek egyik központi értéke az alkalmazkodóképesség. Példaként a Sashkin és Fulmer nevéhez kötődő kérdőív dimenzióit vázoljuk fel (Xenikou - Furnham, 1996 alapján), mert ez az eszköz felel meg a kérdőívek eredményes használatát garantáló érvényesség és megbízhatóság feltételeinek. A Szervezeti hiedelmek kérdőív (Organizational Beliefs Questionnaire - OBQ) 5 fokos Likert skálán mért tíz dimenzió mentén vizsgálódik: A munkának szórakoztatónak kellene lennie (Work should be fun), Legjobbnak lenni, Innováció, Részletekre való figyelem, Emberközpontúság, Minőség, Feladatközpontú kommunikáció, Növekedés/ profit/ egyéb mutatói a sikernek, Menedzsment és a Közös hiedelem fontossága.

E megközelítés legnagyobb hiányossága, hogy eddig nem sikerült közvetlen, egyértelmű, egyirányú kapcsolatot kimutatni bizonyos közös értékek és a szervezetek teljesítménye között (Wilderom - Glunk Maslowski, 2000). Ezzel párhuzamosan egyre erőteljesebben fogalmazódott meg az a nézet, hogy a szervezeti kultúra csak közvetett kapcsolatban áll a szervezeti hatékonysággal, illetve eredményességgel, amint azt a következőkben bemutatott újabb kultúrakutatási irányzat is mutatja.

\section{Illeszkedési felmérések ( $P$-O fit)}

Az egyén-szervezet illeszkedését (Person-Organization fit) vizsgáló kutatások alapfeltevése, hogy a munkavállalói és szervezeti értékek megegyezése hozzájárul a szervezeti tagok elkötelezettségének, lojalitásának növeléséhez, közvetve támogatva a szervezeti teljesítmény javulását is (O'Reilly - Chatman - Caldwell, 1991; Weber, 2000). A teljesítményalapú felmérésektől eltérően a szervezetről az egyénre irányítja a 
figyelmet. A kutatások alapösszefüggése, hogy az egyén szervezetbe való illeszkedése a szervezeti kultúra függvénye. Az interakcionalista pszichológia alaptételének megfelelően feltételezi, hogy adott kontextusban az egyén reakcióját egyéni magatartási jellemzők (értékek, elvárások) és szituációs tényezők (javadalmazási rendszer, normák, szervezeti kultúra) határozzák meg. Ha az egyén illeszkedik, megfelel a szituáció követelményrendszerének, pozitív egyéni válaszok születnek. Amint a fentiekben is láttuk a szervezetikultúra-kutatásokban az értékek vizsgálatának központi szerepe van (Enz, 1988; Hofstede, 1990; Schein, 2004). Az illeszkedési felmérések ezt az állítást a társadalmi identitás elméletekre (Social Identity Theory, Ashforth - Mael, 1989) építve az egyén szintjére is kiterjesztik, az egyéni és szervezeti oldal vizsgálati fókuszába egyaránt az értékeket állítják. Az egyének társadalmi identitásukat például etnikai hovatartozásuk, szakmájuk, szervezeti tagságuk összességével határozzák meg, és a hozzájuk hasonló kategóriákba besorolható egyéneket, csoportokat preferálva különböztetik meg hovatartozásukat. A SIT fenti alaptételét kiindulópontnak tekintve Schneider (1987) azt állítja, hogy az egyének azon szervezetekhez vonzódnak, amelyeknek az értékrendjét az egyéni értékrendjükhöz hasonlónak észlelik. Ennek megfelelője a szervezet oldaláról a kiválasztási, valamint a szervezeti szocializációs folyamatban tapasztalható meg (Trice Beyer, 1993). A fenti gondolatmenetnek megfelelően a hatékonyságalapú felmérésektől eltérően az illeszkedési vizsgálatok nem a szervezeti sikert biztosító szervezeti értékek definiálását tűzték ki célul, hanem a frissen belépők mintáján elemezték azon központi értékek egyezését, amelyek fontosak az egyén identitásának és a szervezet kultúrájának alakulása szempontjából (Enz, 1988). Kevésbé statikus kultúraértelmezéssel vizsgálták továbbá az egyéni értékrendek alakulását a szocializációs folyamatok során.

Az illeszkedési vizsgálatok kezdete O'Reilly Chatman - Caldwell, (1991) nevéhez kötődik, akik a szervezeti kultúra szakirodalmát áttekintve „erős” szervezeti kultúra jellemzőkből 54 értékalapú állítást tartalmazó mérőeszközt (Organizational Culture Profile - OCP) alkottak. A felmérés során Q-sorting technikát alkalmaztak, lehetővé téve, hogy a kutatásban résztvevők határozzák meg, hogy mely kulturális dimenziók relevánsak és melyek nem. A résztvevők kétszer végezték el a rangsorolást, egyszer szervezeti (,Rangsorolja szervezetének kulturális karakterisztikáit, közös normákon vagy elvárásokon alapuló elfogadott viselkedésmintáit aszerint, hogy azok mennyire jellemzőek a szervezetben.”), majd egyéni szinten (,Mennyire fontos, hogy ez jellemző legyen arra a szervezetre, amelynek tagja?"). Mind a szervezeti, mind az egyéni szinten az értékelő állításokat kilenc előre meghatározott kategóriába kellett besorolni - a legkevésbé jellemzőtől/kívánatostól a leginkább jellemző/kívánatos felé haladva - úgy, hogy minden kategóriába adott számú állítást kellett rendelni (a legtöbb állítás a középen található semleges kategóriákba került).

Az egyéni és szervezeti szinten végzett felmérések adatain faktoranalízist végeztek, majd az egyéni szinten meghatározott nyolc, illetve szervezeti szinten azonosított hét faktor tartalmának összehasonlításával öt közös tartalmú faktor körvonalazódott: innováció, eredményorientáció, agresszivitás, részletekre való figyelem és csoport orientáció (O’Reilly - Chatman - Caldwell, 1991). Ezzel egyszersmind az is igazolódott, hogy az illeszkedés vizsgálatára kifejlesztett OCP használható a szervezeti kultúra elemzésére is. Az egyén-szervezet illeszkedés jelentős befolyással volt olyan egyéni szinten mérhető eredményváltozókra, mint az elkötelezettség, munkaköri elégedettség, vagy a munkahely elhagyásának szándéka. Fontos megjegyezni ugyanakkor, hogy az egyén-munkakör illeszkedés (P-J fit) és az egyén-szervezet illeszkedés (P-O fit) közötti összefüggés nem jelentős, viszont egymástól függetlenül befolyásolják a fentiekben felsorolt egyéni eredmény változókat (O'Reilly - Chatman - Caldwell, 1991).

Az illeszkedési vizsgálatok eredményei - kiegészítve a kvantitatív, integrációs elemzésekben feltárt eredményeket - hozzájárulnak a kultúra egyénre gyakorolt hatásának megértéséhez.

\section{A kérdőíves kutatások kulcsdimenziói}

Amint az 1. táblázat is mutatja, az elmúlt évtizedekben a szervezeti kultúra kutatói eltérő relevánsnak tekintett dimenziókra építő számos szervezeti kultúra kérdőívet fejlesztettek ki. Egyetlen kérdőív sem fedi le az összes ismert kultúradimenziót, az eltérő kutatási céloknak megfelelően mindegyik különböző dimenziókra fókuszál, így a használatuk és általánosíthatóságuk is korlátozott. Ennek magyarázata egyszerü: a szervezeti kultúra olyan komplex jelenség, amely lehetetlenné teszi, hogy bármely kutatás is lefedje az összes releváns dimenziót (Cameron - Quinn, 1999). Mindig található legalább még egy plusz dimenzió, amely fontos lehet valamely szervezet kultúrájának leírásához.

Ugyanakkor a különböző kérdőívek segítségével végzett felmérések eredményeit összevetni csak akkor tudjuk, ha sikerül áttekintenünk a különböző dimenziókat és megállapítani, hogy milyen tartalmi átfedések léteznek közöttük. Egymástól függetlenül számos összefoglaló cikk kísérelte meg az előző alfejezetben ismertetett dimenziók integrálását (Ashkanasy Broadfoot - Falkus, 2000; Delobbe - Haccoun - Vandenberghe, 2002; Detert - Schroeder - Mauriel, 2001; 
Szervezeti kultúra kulcsdimenziók

(Fisher et al., (2004) alapján, annak kiegészítésével)

\begin{tabular}{|c|c|c|c|c|c|c|}
\hline $\begin{array}{l}\text { Kulcsdimen- } \\
\text { ziók tartalma }\end{array}$ & Schein (1999) & $\begin{array}{l}\text { Delobbe-Haccoun- } \\
\text { Vander-berghe } \\
(\mathbf{2 0 0 2 )}\end{array}$ & $\begin{array}{l}\text { Detert-Schroeder- } \\
\text { Mauriel (2001) }\end{array}$ & $\begin{array}{l}\text { Ashkanasy- } \\
\text { Broadfoot- } \\
\text { Falkus (2000) }\end{array}$ & $\begin{array}{l}\text { Xenikou- } \\
\text { Furnham } \\
\text { (1996) }\end{array}$ & Referenciák \\
\hline Környezet & $\begin{array}{l}\text { A szervezet } \\
\text { környezethez } \\
\text { való viszonya }\end{array}$ & & $\begin{array}{l}\text { Belső és/vagy } \\
\text { külső fókusz }\end{array}$ & Környezet & & $\begin{array}{l}\text { Hofstede (1990); Quinn (1988); } \\
\text { Sashkin-Fulmer (1985); House et } \\
\text { al., (2004a); Patterson et al., (2005) }\end{array}$ \\
\hline Motiváció & $\begin{array}{l}\text { Az emberi } \\
\text { természet } \\
\text { természete }\end{array}$ & & Motiváció & $\begin{array}{l}\text { Szervezeti } \\
\text { szocializáció, } \\
\text { Az egyén } \\
\text { fejlesztése }\end{array}$ & Hatalom & $\begin{array}{l}\text { Hofstede (1990); Sashkin-Fulmer } \\
\text { (1985), House et al. (2004a) }\end{array}$ \\
\hline Innováció & & Innováció & $\begin{array}{l}\text { Stabilitás vs. } \\
\text { változás } \\
\text { innováció } \\
\text { személyes } \\
\text { fejlődés }\end{array}$ & Innováció & Innováció & $\begin{array}{l}\text { Cooke-Lafferty (1986); Hofstede } \\
\text { (1990); Kilmann-Saxton (1983); } \\
\text { O’Reilly-Chatman-Caldwell } \\
\text { (1991); Quinn (1988); Sashkin- } \\
\text { Fulmer (1985), House et al., } \\
\text { (2004a); Patterson et al., (2005) }\end{array}$ \\
\hline $\begin{array}{l}\text { Igazság } \\
\text { természete }\end{array}$ & $\begin{array}{l}\text { A valóság és } \\
\text { igazság } \\
\text { természete }\end{array}$ & $\begin{array}{l}\text { Igazság és racio- } \\
\text { nalitás természete } \\
\text { a szervezetekben }\end{array}$ & & & & $\begin{array}{l}\text { Hofstede (1990); Sashkin-Fulmer } \\
\text { (1985) }\end{array}$ \\
\hline $\begin{array}{l}\text { Idóter- } \\
\text { mészete }\end{array}$ & $\begin{array}{l}\text { Az idő ter- } \\
\text { mészete }\end{array}$ & & $\begin{array}{l}\text { Az idő természete } \\
\text { és időorientáció } \\
\text { (múlt, jelen, jövő) }\end{array}$ & Tervezés & & $\begin{array}{l}\text { Quinn (1988); Sashkin-Fulmer } \\
\text { (1985); House et al., (2004a) }\end{array}$ \\
\hline $\begin{array}{l}\text { (Munka) } \\
\text { szervezés }\end{array}$ & $\begin{array}{l}\text { Az emberi } \\
\text { kapcsolatok } \\
\text { természete }\end{array}$ & & $\begin{array}{l}\text { Elszigetelődés vs. } \\
\text { együttműködés }\end{array}$ & & & $\begin{array}{l}\text { Hofstede (1990); Kilmann-Saxton } \\
\text { (1983); O’Reilly-Chatman-Cald- } \\
\text { well (1991); Quinn (1988); Sash- } \\
\text { kin-Fulmer (1985); House et al., } \\
\text { (2004a); Patterson et al., (2005) }\end{array}$ \\
\hline $\begin{array}{l}\text { Feladat vs. } \\
\text { emberköz- } \\
\text { pontúság }\end{array}$ & & $\begin{array}{l}\text { Emberközpontú- } \\
\text { ság. Eredmény- } \\
\text { orientáció }\end{array}$ & $\begin{array}{l}\text { Munka, feladat } \\
\text { és munkatársak } \\
\text { fontossága }\end{array}$ & $\begin{array}{l}\text { Humánus } \\
\text { munkahely. } \\
\text { Munkahelyi } \\
\text { teljesítmény }\end{array}$ & $\begin{array}{l}\text { Feladat-ori- } \\
\text { entált szer- } \\
\text { vezeti növe- } \\
\text { kedés. Hu- } \\
\text { mánorien- } \\
\text { táció }\end{array}$ & $\begin{array}{l}\text { Cook-Lafferty (1986); Hofstede } \\
\text { (1990); Kilmann-Saxton (1983); } \\
\text { O’Reilly-Chatman-Caldwell } \\
\text { (1991); Quinn (1988); Sashkin- } \\
\text { Fulmer (1985); House et al., } \\
\text { (2004a); Patterson et al. (2005) }\end{array}$ \\
\hline Kontroll & & Kontroll & $\begin{array}{l}\text { Kontroll, } \\
\text { koordináció és } \\
\text { felelősség }\end{array}$ & $\begin{array}{l}\text { Struktúra } \\
\text { Leadership } \\
\text { Kommuni- } \\
\text { káció }\end{array}$ & Kontroll & $\begin{array}{l}\text { Hofstede (1990); Kilmannet Sax- } \\
\text { ton (1983); O'Reilly-Chatman- } \\
\text { Caldwell (1991); Quinn (1988); } \\
\text { Sashkin-Fulmer (1985); House et } \\
\text { al., (2004); Patterson et al., (2005) }\end{array}$ \\
\hline
\end{tabular}

Fisher et al. (2004); Xenikou - Furnham, 1996). Jelen áttekintésben, Schein (1999) dimenzióit tekintve kiindulási pontnak, kiegészítem őket az összefoglaló cikkekben azonosított fóbb kulturális dimenziókkal, és tartalmuk szerint csoportosítva, definiálom azt a nyolc kulcsdimenziót, melyeket az ismertetett dimenziók csak részlegesen fednek le, egymást kiegészítve (2. táblázat).

- Környezet (külső vs. belső orientáció; nyílt vs. zárt rendszer orientáltság):

Számos kutatás a szervezet és környezete közötti kapcsolat természetét a szervezeti kultúra központi elemeként tartja számon. A szervezeteket megkülönböztethetjük annak függvényében, hogy a belső folyamatokra és munkavállalóikra fókuszálnak, vagy inkább a fogyasztókra, versenytársakra és külső környezetükre (Schein, 1999). Az első csoportba tartozó szervezetek tevékenységét a menedzserek, mérnökök, belső szakértők határozzák meg, míg a második csoportba tartozókét inkább a fogyasztók elvárásai, valamint a best practice benchmarkok (Detert - Schroeder - Mauriel, 2001).

- Motiváció (az emberi természetre és a munkavállaló motivációjára vonatkozó feltételezések):

Az embert külső vagy belső motivációi mozgatják, az ember természete jó vagy rossz, változtatható-e vagy sem, az embereket jutalmazni vagy büntetni kell, az eredmények változtathatóak-e vagy sem mások motivációjának manipulációja által - ezek mind lényegi összefüggései az egyéni motiváció kérdéskörének, ami központi eleme az egyén szervezeti magatartásának, s mint ilyen gyakran felbukkan a szervezeti kultúra vizsgálódásokban is (Schein, 1999; Ashkanasy - Broadfoot - Falkus, 2000). Elméleti alapját McClelland implicit motivációs elmélete képezi (McClelland, 1965, 1976), mely az emberi viselkedés mögött három alapvető, tudatalatti (implicit) indítékot feltételez (kapcsolat/ elfogadottság, teljesítmény/belső hajtóerő a sikerre, 
hatalom/befolyásolás), melyek tanultak, és nem örökletes jellegúek, azaz kulturálisan meghatározottak, különböző társadalmakban (szervezetekben) eltérő jellemzőket mutatnak,

- Innováció (stabilitás és elöre jelezhetöség vs. innováció és szervezeti változás):

Az összes vizsgált kultúra-kérdőívben felbukkant ez a dimenzió, melynek egyik központi gondolata a stabilitás vs. változás igényével kapcsolható össze. Amikor a szervezet egésze a kockázatvállalás szükségességét hirdeti, a szervezeti innováció központi fogalommá válik. Az innovációorientált szervezetek igénylik a folyamatos fejlesztést, és az egyik szervezeti hiedelmük, hogy képesek mindig valami jobbat elérni (Sashkin - Fulmer, 1985). A kockázatkerülő szervezetekben az „elég jót” alkotni gondolkodás az uralkodó (Detert - Schroeder - Mauriel, 2001).

- Az igazság természete

(az igazság és a tudás meghatározása):

A szervezetekben az egyének eltérő feltevéseikkel élnek a valóság természetéről, valamint az igazság meghatározhatóságáról. Ennek függvényében a szervezeti tagok igazságként fogadhatják el azt, amit a szakértők, a hatalommal rendelkezők állítanak, amit saját tapasztalataik sugallnak, vagy amit a hagyományok, a vallás határoz meg számukra (Schein, 1999).

- Az idő természete (az idő természetének meghatározása, valamint az időorientáció):

Schein (1999) ezen dimenzió kapcsán az idő természetének meghatározására, valamint az idő fontosságára koncentrál, míg más kutatók az időorientációt helyezik a középpontba (múlt, jelen vagy jövő). Az időorientáció határozza meg, hogy egy adott szervezetben a hosszú távra való tervezést vagy az itt és most megélését részesítik előnyben.

- (Munka) Szervezés (egyéni vagy csoportos munkavégzés):

$\mathrm{Az}$ áttekintett kutatások mindegyike tartalmaz az egyéni vagy csoportos munkavégzés fontosságára vonatkozó dimenziót. A dimenziók mögött az emberi kapcsolatokra, valamint a hatékony munkavégzés megszervezésére vonatkozó feltevések húzódnak meg (Schein, 1999). Adott szervezetekben a munkát az egyének végzik, a közös munkavégzést nem találják hatékonynak, vagy az egyéni szabadság megsértésének tartják. Más szervezetekben a jobb döntések és eredmények kulcsát látják az együttműködésben. Itt nem az egyes egyének, hanem a csoport végzi a feladatokat.

- Feladat vs. emberközpontúság:

$\mathrm{Az}$ áttekintett kutatások jelentős része tartalmaz olyan kulturális dimenziót, amely a munka fontosságát, valamint a munka és magánélet közötti egyen- súly gondolatát tartalmazza. Bizonyos kultúrákban maga a munka jelenti a végső célt, másokban pedig csupán eszköz a „minőségi, jó élet” elérésében (Detert - Schroeder - Mauriel, 2001). Előbbiben a feladat, utóbbiban a munkahelyi kapcsolatok a fontosabbak.

- Kontroll (formalizáltság mértéke, a felelösség megosztása):

A szervezetek megkülönböztethetőek annak függvényében, hogy a kontroll mennyire központosított. Azon szervezetekben, ahol a kontroll központosított, a szabályozottság, valamint a központi döntéshozatal a jellemző, míg azon szervezetekben, ahol ez kevésbé jellemző a rugalmasság, és egyéni felelősségvállalás, mint központi érték jelenik meg.

\section{Következtetések}

Tanulmányomban elhelyeztem a kérdőíves kultúrakutatásokat a szervezeti kultúra kutatások terében, kultúra kérdőív tipológiát definiáltam a vizsgált szervezeti kultúra szint (magatartás, érték) és az elemzés célja (kultúra tipológia kialakítása, összehasonlítás, kultúra és szervezeti, valamint egyéni eredményváltozók közötti összefüggések) függvényében, valamint áttekintettem a szervezeti kultúra kulcsdimenzióit.

$\mathrm{Az}$ elvégzendő újabb kutatások két irányban is továbbfejleszthetik a vizsgált kutatások körét: 1) a kulcsdimenziók belső struktúrájának a feltárására törekedve a fentiekben definiált kulcsdimenziók relevanciájának empirikus vizsgálata és elemzése eltérő iparágakban, régiókban - például az innovációs dimenzió mentén feltételezhetóen nagyobb szervezeti különbségek mutathatóak majd ki a csúcstechnológiával dolgozó szervezetek esetében, mint a hagyományos iparágakban (pl. élelmiszeripar) tevékenykedő szervezetek esetében; 2) elmozdulni a jelen kutatásokra jellemző statikus kultúramodell felől egy dinamikus kultúramodell kialakítása felé, a kultúra több szinten való vizsgálata (multi-level approach) révén.

\section{Felhasznált irodalom}

Allaire, Y. - Firsirotu, M. E. (1984): Theories of organisational culture. Organisation Studies, 5(3), pp. 193 - 226.

Allen, R. F. - Dyer, F. J. (1980): A tool for tapping the organizational unconscious. Personnel Journal, 59(3), pp. $192-199$.

Ashforth, B. E. - Mael, F. (1989): Social identity theory and the organization. Academy of Management Review 14(1), p. 20-39.

Ashkanasy, N. M. - Broadfoot, L. E. - Falkus, S. (2000): Questionnaire measures of organizational culture in: Ashkanasy, N. M. - Wilderom, C. P. M. - Peterson, M. F. (eds.): Handbook of Organizational Culture and Climate, SAGE Publications, pp. $131-147$.

Ashkanasy, N. - M. Wilderom, P. M. - Peterson, M., F. (2000): Introduction, in: Ashkanasy, N. M. - Wilderom, C. P. M. Peterson, M. F. (eds.): Handbook of Organizational Culture and Climate, SAGE Publications, pp. 1-18. 
Bakacsi, Gy. (1996): Szervezeti magatartás, Aula, Budapest

Bakacsi, Gy. (2006): Kultúra és gazda(g)ság - a gazdasági fejlődés és fejlettség és a GLOBE kultúra-változóinak összefüggései, Vezetéstudomány, Különszám

Bakacsi, Gy. - Takács, S. (1998): Honnan - hová? A nemzeti és szervezeti kultúra változásai a 90 - es évek közepének Magyarországán. Vezetéstudomány, 2. sz.

Barley, S. (1983): Semiotics and the study of occupational and organizational cultures. Administrative Science Quarterly, pp. 24-60.

Barley, S. R. - Meyer, G. W. - Gash, D. C. (1988): Cultures of culture: academics, practitioners and the pragmatics of normative control. Administrative Science Quarterly, 32(3), pp. 24-?6.

Bíró, B. - Serfözö M. (2003): Szervezetek és kultúra. in Hunyady, Gy. - Székely, M. (szerk.): Gazdaságpszichológia, Osiris, Budapest, 481-541. o.

Bokor, A. (2000): Szervezeti kultúra és tudásintegráció: a termékfejlesztés problémája. PhD értekezés, Kézirat, Budapesti Közgazdaságtudományi és Államigazgatási Egyetem

Brown, A. (1995): Organisational culture. Pitman Publishing, London

Cameron, K. S. - Quinn, R. E. (1999): Diagnosing and changing organizational culture based on the Competing Values Framework. Addison - Wesley Publishing

Chatman, J. A. - Jehn, K. A. (1994): Assessing the relationship between industry characteristics and organizational culture: How different can you be? Academy of Management Journal, 37, pp. 522-553.

Cooke, R. A. - Szumal, J. L. (2000): Using the Organizational Culture Inventory to understand the operating cultures of organizations. in: Ashkanasy, N. M. - Wilderom, C. P. M. - Peterson, M. F. (eds.): Handbook of Organizational Culture and Climate, SAGE Publications, pp. 147-162.

Delobbe, N. - Haccoun, R. R. - Vandenberghe, C. (2005): Measuring core dimensions of organizational culture: a review of research and development of a new instrument. pp. 1-31 http:// www.iag.ucl.ac.be/recherche/Papers/wp53.pdf Letöltve: 2005.08.28.

Denison, D. R. (1996): What is the difference between organizational culture and climate? A native's point of view on a decade of paradigm wars. Academy of Management Review, 21(3), pp. 619-654.

Detert, J. R. - Schroeder, R. G. - Mauriel, J. J. (2000): A framework for linking culture and improvement initiatives in organizations, Academy of Management Review, 25(4), pp. 850-863.

Enz, C. A. (1988): The role of value congruity in intraorganizational power. Administrative Science Quarterly, pp. 287-304.

Fisher, R. - Ferreira, M. C. - Assmar E. M. L. - Redford, P. Harb, C. (2004): Organisational behaviour across cultures: theoretical and methodologocal issues for developing multi-level frameworks involvolving culture. Manuscript

Giddens, A. (1995): Szociológia. Osiris Kiadó

Gordon, G. G. - DiTomaso, N. (1992): Predicting corporate performance from organizational culture. Journal of Management Studies, 29(6), pp. 783-798.

Gupta, V. - de Luque, M.S. - House, R. J. (2004): Multisource construct validity of GLOBE scales, in: House, R. J. - Hanges, P. J. - Javidan, M. - Dorfman, P.W. - Gupta, V. (eds.): Culture, Leadership and Organizations. The GLOBE study of 62 societies, SAGE Publications, pp. 152-164.

Heidrich, B. (2000): Szervezeti kultúra és interkulturális menedzsment. Bíbor Kiadó, Miskolc

Hofstede, G. (2001): Culture's consequences: comparing values, behaviors, institutions and organizations across nations. SAGE Publications

Hofstede, G. - Neuijen, B. - Ohayv, D. D. - Sanders, G. (1990): Measuring organizational cultures: a qualitative and quantita- tive study across twenty cases. Administrative Science Quarterly, 35, pp. 286-316.

House, R. J. - Hanges, P. J. - Javidan, M. - Dorfman, P. W. Gupta, V. (eds.) (2004a): Culture, Leadership and Organizations. The GLOBE study of 62 societies. SAGE Publications House, R. J. - Hanges, P. J. (2004b): Research design, in: House, R. J. - Hanges, P. J. - Javidan, M. - Dorfman, P. W. - Gupta, V. (eds.): Culture, Leadership and Organizations. The GLOBE study of 62 societies, SAGE Publications, pp. 95-101.

Jávor, I. - Rozgonyi, T. (2005): Hatalom, konfliktus, kultúra. KJK

Klein, S. (2002): Vezetés - és szervezetpszichológia. SHL Hungary Kft., Budapest

Mármarosi, A. (2002): Szervezeti kultúra típusok a '90-es évek végén Magyarországon. Vezetéstudomány, 6. 2-16. o.

Martin, J. (2002): Organizational culture: mapping the terrain. SAGE Publications

Martin, J. - Frost, P. J. - O’Neill, O.A. (2004): Organizational culture: beyond stuggle for intellectual dominance. Research paper no. 1864, Stanford Graduate School of Business

Martin, J. - Feldman, M. - Hatch, M. - Sitkin, S. (1983): The uniqueness paradox in organizational stories. Administrative Science Quarterly, 438-453 o.

Meyerson, D. - Martin, J. (1987): Cultural change: an integration of three different views. Journal of Management Studies, 24, pp. 623-647.

McClelland, D. C. (1965): Achievement motivation can be developed. Harvard Business Review, November-December

McClelland, D. C. - Burnham, D. H. (1976): Power is the great motivator, Harvard Business Review, pp. 100-110.

O'Reilly, C. A. - Chatman, J. - Caldwell, D. F. (1991): People and organizational culture: a profile comparison approach to assessing person - organization fit. Academy of Management Journal, 34(3), pp. 487-516.

Parker, M. (2000): Organizational culture and identity. Sage Publications, London

Patterson, M. G. - West, M. A. - Shackleton, V. J. - Dawson, J. F. Lawthom, R. - Maitlis, S. - Robinson, D. L. - Wallace, A. M. (2005): Validating the organizational climate measure: links to managerial practices, productivity and innovation. Journal of Organizational Behavior, pp. 379-408.

Peters, T. J. - Waterman, R. H. (1982): In search of excellence. Lessons from America's best run companies. Harper \& Row, New York, (magyarul Peters, T. J. és Waterman, R. H. (1986): A siker nyomában, Kossuth Könyvkiadó - Közgazdasági és Jogi Könyvkiadó, Budapest)

Pettigrew, A. M. (1979): On studying organizational cultures. Administrative Science Quarterly, 24(4), pp. 570-581.

Quinn, R. E. - Rohrbaugh, J. (1983): A spatial model of effectiveness criteria: Toward a competing values approach to organizational analysis. Management Science. 29, pp. 363- 377.

Robert, C. - Wasti, S. A. (2002): Organizational individualism and collectivism:theoretical development and an empirical test of a measure. Journal of Management, 28(4), pp. 544-566.

Schein E. H. (2004): Organisational Culture and Leadership (3rd ed.). Jossey-Bass

Schein, E.H. (1999): The corporate culture: survival guide. JosseyBass

Schneider, B. (1987): The people make the place. Personnel Psychology, 40, pp. 437-453.

Smirchich, L. (1983): Concepts of culture and organizational analysis. Administrative Science Quarterly, 28, pp. 339-358.

Trice, H. M. - Beyer, J. M. (1993): The cultures of work organizations. Prentice Hall

Van Muijen, J. J. - Koopman, P. - De Witte, K. - De Cock, G. Susanj, Z. - Lemoine, C. - Bourantas, D. - Papalexandris, N. Branyiczky, I. - Spaltro, E. - Jesuino, J. - Gonzalves Das Neves, J. - Pitariu, H. - Konrad, E. - Peiro, J. - Gonzales- 
Roma, V. - Turnipseed, D. (1999): Organizational culture: The FOCUS questionnaire. European Journal of Work and Organizational Psychology, 8, pp. 551-568.

Verbeke, W. - Volgering, M. - Hessels, M. (1998): Exploring the conceptual expansion within the field of organizational behaviour: organizational climate and organizational culture. Journal of Management Studies, 35(3), pp. 303-329.

Weber, Y. (2000): Measuring cultural fit in: Mergers and Acquisitions. in: Ashkanasy, N. M. - Wilderom, C. P. M. Peterson, M. F. (eds.): Handbook of Organizational Culture and Climate, SAGE Publications, pp. 309-320.

Wilderom, C. P. M. - Glunk, U. - Maslowski R. (2000) Organizational culture as predictor of organizational performance, in: Ashkanasy, N. M. - Wilderom, C. P. M. - Peterson, M.F. (eds.): Handbook of Organizational Culture and Climate, SAGE Publications, pp. 193-209.

Xenikou, A. - Furnham, A. (1996): A correlational and factor analytic study of four questionnaire measures of organizational culture. Human Relations, 49(3), pp. 349-371.

\section{Lábjegyzetek}

${ }^{1}$ Menedzseri megközelítésről beszélünk, ha a szervezeti kultúra feltárásában és megértésében a szervezeti teljesítmény növelésének egyik lehetséges eszközét látják a kutatók, menedzseri érdekeket szolgálva (Martin, 2002). A kritikai kultúrakutatások feltárják a szervezeti szereplők közötti konfliktusokat, bizonyítják, hogy a szervezeti gyakorlat csak bizonyos szervezeti szereplők érdekeit szolgálja, másokat pedig elhallgattat. Martin (2002) szűkebb értelmezését adja a kritikai megközelítésnek, nem társít hozzájuk episztemológiai és módszertani elvárásokat.
${ }^{2}$ A vizsgált kutatások (specialista, integrációs, menedzseri és kérdőívalapú) a szervezeti kultúra fogalmát a klímáéhoz hasonlóan szervezeti változóként értelmezik, melyet deduktív módon, kérdőívek segítségével tárnak fel (Ashkanasy - Wilderom Peterson, 2000). Felmerül a kérdés, hogy a vizsgált kutatások esetében mégis miért szervezeti kultúráról és nem klímáról beszélünk? A kérdésre a választ a két fogalom közötti lényeges különbségek jelentik: 1) eltérő társadalomtudományokban gyökereznek (Denison, 1996); 2) más-más szervezeti jellemzőkre helyezik a hangsúlyt (Verbeke - Volpering - Hessels, 1998). A klíma fogalmának gyökerei a Gestalt pszichológiában találhatóak, Lewin - Lippit - White (1939) használta először, míg a szervezeti kultúra fogalmának gyökerei a szociológiában, valamint kulturális antropológiában fedezhetőek fel (Denison, 1996). Verbeke -Volpering - Hessels (1998) a fogalmak különböző meghatározásain végzett tartalomelemzésük alapján állítják, hogy a szervezeti klíma kutatói a szervezeti gyakorlat egyének által való észlelésére, míg a szervezeti kultúra kutatói a szervezeti normákra, értékekre és hiedelmekre, valamint a kultúra tanulhatóságára, közös (shared) jellegére helyezik a hangsúlyt.

${ }^{3}$ Az egyes szervezet és kultúra típusok részletes magyar leírása megtalálható a Bakacsi (1996), Heidrich (2000), Klein (2002), vagy a Hunyadi (2003) könyvek szervezeti kultúrára vonatkozó fejezeteiben.

${ }^{4}$ A tengelyeknek, valamint a kultúra típusoknak magyar leírása fellelhető a Bakacsi (1996), Heidrich (2000) írásaiban.

${ }^{5}$ Hofstede (2001) eltérő dimenziókat javasol a nemzeti kultúrák, valamint a szervezeti kultúrák vizsgálatára. A klasszikusnak számító (hatalmi távolság, bizonytalanságkerülés, individualizmus/ kollektivizmus, nőies/férfias, hosszú/rövid távú gondolkodás) dimenziók használata a nemzetközi összehasonlító kultúra-kutatásokban javasolt.

\section{E számunk szerzői}

PRIMECZ Henriett, egyetemi adjunktus, Budapesti Corvinus Egyetem; TOARNICZKY Andrea, tanársegéd, Budapesti Corvinus Egyetem; KARÁCSONYI András, PhD hallgató, Budapesti Corvinus Egyetem; Dr. BAKACSI Gyula, egyetemi docens, tanszékvezető, Budapesti Corvinus Egyetem; SZŐTS-KOVÁTS Klaudia, tanársegéd, Budapesti Corvinus Egyetem; TAKÁCS Sándor, $\mathrm{PhD}$, egyetemi docens, Budapesti Corvinus Egyetem; VÁRADI SZABÓ Zsuzsa, PhD hallgató, Budapesti Corvinus Egyetem; Dr. GELEI András, egyetemi docens, Budapesti Corvinus Egyetem. 